\title{
Marie-Claire Bergère, Capitalismes et capitalistes en Chine des origines à nos jours
}

Lucien Bianco

\section{(2) OpenEdition}

1 Journals

\section{Electronic version}

URL: http://journals.openedition.org/chinaperspectives/3923

DOI: 10.4000/chinaperspectives.3923

ISSN: 1996-4617

\section{Publisher}

Centre d'étude français sur la Chine contemporaine

\section{Printed version}

Date of publication: 4 April 2008

Number of pages: 110-112

ISSN: 2070-3449

\section{Electronic reference}

Lucien Bianco, «Marie-Claire Bergère, Capitalismes et capitalistes en Chine des origines à nos jours », China Perspectives [Online], 2008/2 | 2008, Online since 01 April 2008, connection on 24 September 2020. URL : http://journals.openedition.org/chinaperspectives/3923 ; DOI : https://doi.org/10.4000/ chinaperspectives.3923

This text was automatically generated on 24 September 2020.

(c) All rights reserved 


\title{
Marie-Claire Bergère, Capitalismes et capitalistes en Chine des origines à nos jours
}

\author{
Lucien Bianco
}

1 A capitalism without capitalists? This is the paradox that Marie-Claire Bergère invites us to consider in her latest book, and which eventually persuades us. Certainly there are capitalists, and outrageously rich ones, too, who show off their riches and go for ostentatious consumption. But that is precisely the point; many of them give priority to consumption over accumulation, unlike the Protestant ethic according to Max Weber or the Confucian virtues of work and saving, because they are only too aware of the precariousness of their position and the uncertainty looming over their future (p. 322).

The state has promoted or protected them - not all, of course, but quite a lot of them; the political elite has co-opted them or selected them from among its own members ("a classic merging of elites, which happens after every revolution," p. 306), and they have to maintain good relations with the decision-makers and power-brokers: one of them, by no means a minor figure, acknowledges that "he spends two thirds of his time on political matters" (p. 324). The same state, or more precisely the same Communist Party, that welcomes into its midst the "progressive productive forces" (following the doctrine of the Three Represents launched by Jiang Zemin in 2001) and admits company bosses into its schools (p. 326) may also hurl them down by suspending their licenses, permits, or market access ("beyond a certain very low threshold, no firm can develop without support from official agencies," p. 315), or by accusing them of tax evasion, fraud, smuggling, or anything else.

When it is not the government behind some spectacular collapse or other, it is the price wars, the tricky twists from the competition, the thousandand- one practices of unrestrained capitalism, or the disastrous speculative bids that condemn many entrepreneurs to a career that is both stormy and short. Moreover, they arouse others' envy. Those most struck by jealousy see red (hongyan bing, "the red-eyed disease") and even go so far as to murder the over-achievers. In vain did Deng play the Guizot role, 
while today's government distributes honorific baubles to his "model creators" of money and jobs. ${ }^{1}$ Twenty-five years of Maoist indoctrination have left their mark, and egalitarianism pours suspicion on any- one who rises above others. Hatred of the wellheeled, the parasites, the privileged, the speculators, and the bloodsuckers is still widely shared in China. This feeling does not prevent, however, the worship of money and the lust for consumption from uniting the well-off with those who aspire to join them and those who have no chance of doing so. In that respect, the capitalists simply participate in the most commonly shared tastes and values in China today, and cannot be credited with any originality in that respect, either (p. 320).

4 Completely at one with run-of-themill opinion, the capitalists are no more inclined to spurn the goals of the government: economic prosperity and social stability. The main point is this consensus of the elite. It is a collusion between the government and the entrepreneurs, which serves as a cover for the subservience of the latter towards the former. The entrepreneurs are quite the opposite of a "triumphant bourgeoisie with its own social and political demands" (p. 364). The author mockingly describes them as a "consenting bourgeoisie" (p. 366). Democracy is not on the agenda.

5 Nor is revolution, she adds to complete the picture. Mao once warned that "if the system becomes socialist in name but capitalist in fact, our grandchildren will certainly rise up." But although the first of his conditions has been met, "the grandchildren are hardly thinking about revolution" (p. 367). The poverty carefully preserved by Mao himself makes them appreciate all the more that average per capita income has increased eightfold over the last 25 years, and that China is now classified among the countries with a medium annual income (p. 242). That is the other side of the coin; this unrestrained, precarious, hybrid capitalism is nonetheless a dynamic capitalism (p. 267). Far from being a cardboard creature, supported at arm's length by the state that has it at its mercy, it is thriving in its own way, and letting China thrive with it. All things considered, it actually benefits - for the time being - from the state action that created and controls it. That state itself, without giving any of its essential powers away, is sufficiently flexible to adapt, and has more or less come to terms with the possible harm to itself from what it has unleashed.

6 As for the harmful consequences for the people or for the country, or for both, we should first of all be aware of the very high social costs arising from restructuring the state sector (p. 251), and secondly, of the enormous environmental damage and the extreme social inequality caused by the rapid rate of the modernising process, which is still incomplete: "the conditions for sustainable development are far from being met" (p. 252). It might be objected that these are matters related to the drawbacks of economic modernisation rather than the faults of the capitalists themselves. So let us add some precise data well known to the readers of this journal, and eloquently recalled on pages $279-283$ of the work in question: the condition of virtual slavery imposed on the workers, male and female, labouring to pay off the debts incurred when they were taken on, the confiscation of identity cards and work and residential permits, the working day of 12 hours or more, the stifling, locked dormitories closely watched by armed guards, the wages paid only months later, and the small, high-risk mines with death rates as high as 2.2 percent: more than one miner out of every five hundred!

7 Admittedly this description does not cover the whole of contemporary Chinese capitalism, but only one aspect and certain sectors, and within those sectors only 
certain enterprises. Apart from these abuses, which evoke shades of Dickens and the industrial revolution in Europe, this hybrid capitalism, which seems to be a creation of communist rule, is also the inheritor of experiences prior to 1949 , or even 1979, in China: the hesitant first steps and the failures as well as the shortlived successes. It is here that the first half of the book, dealing with history, proves essential for understanding the current phase: "the present day modernisers often find themselves facing problems already met by the pioneers of the pre-revolutionary epoch [....] and the power of historical precedent or the simple weight of certain cultural factors still give rise to practices comparable to a past that is not so distant after all" (p. 223). Among those pioneers (who enjoyed limited success), the modernising mandarins such as Li Hongzhang (Chapter 2) deserve just as much attention as the Nationalist government (Chapter 4). In both cases the role of the state (central or regional) was preponderant, just as it is today, and as it has been in every case of belated modernisation (p. 13), from Germany to Japan, and even including France. Conversely, the ephemeral "golden age" of Chinese capitalism between 1911 and 1927 (Chapter 3) owed nothing to state aid and even benefited from the decline of the state. The capitalists of those glory days also brought with them the weight of certain cultural factors, and some of the practices and special features that are still to be found today. These include the trust in spoken transactions, for example, or the well-known reliance on networks of family or regional solidarity (nowadays, the Wenzhou network). The hybrid character of contemporary Chinese capitalism was there from the beginning, the result of the meeting of two systems, native and imported. Imported, but adapted with considerable flexibility and pragmatism: "the challenge from the West was taken up within pre-existing institutions and value systems," and modernisation progressed for better and for worse by successive accommodations rather than through sharp breaks (p. 11).

8 Purists may sniff, but we are certainly a long way from our model capitalism (or to be more precise, the one that developed in England). This capitalism with a Chinese flavour deviates decidedly from the sacrosanct principles of economic rationality. The author of this book is not at all intimidated by rules with universal claims to describe an ideal entity. She persistently sets about understanding a system existing in reality, which was established bit by bit, with a good dose of pragmatism (and idiosyncrasy), and which has proved resilient so far. She makes no apology for an approach focused on deciphering the real situation. This work is a masterful synthesis, crowning a body of work that has always been careful to match first-hand historical research ${ }^{2}$ with reflections on the contemporary world. ${ }^{3}$ These two concerns come together here and resonate throughout the book, because the questions the author raises are matters of concern to one epoch as much as to another, and they often persist across them as the actors strain to find a solution. We rediscover them now, and rediscover ourselves within them all the more easily thanks to this writer's lucid language, her controlled exposition, and the way the turns in her argument always prepare for developments to come. The reader benefits from the rhetorical ease learnt in Sèvres. As an extra bonus for those in a hurry who are put off by research, in the space of about 30 pages Chapter 6 provides an excellent introduction to the recent period, which is a veritable historical guide to the economics of the era of the reforms. So, do I have no criticism at all to offer this author, who has been my colleague for the last half-century? With some effort I can manage to find an objection to her concluding reference to a "state with rule of law" (p. 368), which is rather hastily formulated before being handled more 
circumspectly (p. 369). We have heard rather too much about this notion recently (because of the Olympic Games, and that torch) and about how human rights are being frustrated by the so-called Stalinist totalitarianism that is supposed to be rife in China (Laurent Joffrin). But I still find it difficult to swallow (and lend credibility to) a formulation that I know the Chinese government has made its own.

\section{NOTES}

1. It would seem, as Gilles Guiheux suggests, that the entrepreneur replaced Lei Feng as a model hero ("L'entrepreneur, héros socialiste": a paper given on the occasion to mark the 100th issue of Perspectives chinoises, Paris, CNRS, 5 March 2008).

2. Of particular note, among others, is her L'Age d'or de la bourgeoisie chinoise, 1911-1927, Paris, Flammarion, 1986.

3. In this respect, among equally numerous publications, Le Mandarin et le compradore: les enjeux de la crise en Asie Orientale, Paris, Hachette, 1998. 